\title{
GENERAL THREE-POINT QUADRATURE FORMULAE WITH APPLICATIONS FOR $\alpha-L-$ HÖLDER TYPE FUNCTIONS
}

\author{
M. Klaričić BaKUla, J. PeČARić, M. RibičIĆ PENAVA
}

Abstract. In this paper we present two types of general three-point weighted quadrature formulae. The obtained formulae are used to establish several Ostrowski type inequalities for $\alpha$ - $L$-Hölder functions and some error estimates for three-point Gauss-Chebyshev quadratures.

Mathematics subject classification (2000): 26D15, 65D32.

Key words and phrases: Three-point quadrature formulae, Montgomery identity.

\section{REFERENCES}

[1] A. AgLiĆ AlJinović, J. PeČARIĆ, Extensions of Montgomery identity with applications for $\alpha-L$-Hölder type functions, J. Concr. Appl. Math., 5 (1) (2007), 9-24.

[2] G. A. Anastassiou, Ostrowski type inequalities, Proc. Amer. Math. Soc., 123 (1995), 3775-3781.

[3] D. S. Mitrinović, J. E. PeČARIĆ, A. M. FinK, Inequalities for functions and their Integrals and Derivatives, Kluwer Academic Publishers, Dordrecht (1994).

[4] J. PeČARIĆ, On the Čebyšev inequality, Bul. Inst. Politehn. Temisioara, 25 (39) (1980), 10-11.

[5] A. Ralston, P. RABINOWITZ, A First Course in Numerical Analysis, Dover Publications, Inc., Mineola, New York (2001). 